The Birth of the Anthropocene 
The publisher gratefully acknowledges the generous support of Deborah \& David Kirshman/Helzel Family Foundation, Judith \& Kim Maxwell, and Barclay \& Sharon Simpson as members of the Literati Circle of the University of California Press Foundation. 


\title{
The Birth of the Anthropocene
}

\author{
JEREMY DAVIES
}

따 
University of California Press, one of the most distinguished university presses in the United States, enriches lives around the world by advancing scholarship in the humanities, social sciences, and natural sciences. Its activities are supported by the UC Press Foundation and by philanthropic contributions from individuals and institutions. For more information, visit www.ucpress.edu.

University of California Press

Oakland, California

(C) 2016 by The Regents of the University of California

Library of Congress Cataloging-in-Publication Data

Names: Davies, Jeremy, 1983- author.

Title: The birth of the Anthropocene / Jeremy Davies.

Description: Oakland, California : University of California Press, [2016] | "2016 | Includes

bibliographical references and index.

Identifiers: LCCN 2015043076 (print) | LCCN 2016005793 (ebook) | ISBN 9780520289970 (cloth : alk. paper) | ISBN 9780520289987 (pbk. : alk. paper) | ISBN 9780520964334 (e)

Subjects: LCSH: Global environmental change. | Nature-Effect of human beings on. | Environmental geology. | Paleoecology-Holocene.

Classification: LCC GE149.D38 2016 (print) | LCC GE149 (ebook) | DDC 304.2-dc23

LC record available at http://lccn.loc.gov/

2015043076

Manufactured in the United States of America

$\begin{array}{llllllllll}25 & 24 & 23 & 22 & 21 & 20 & 19 & 18 & 17 & 16\end{array}$

$\begin{array}{llllllllll}10 & 9 & 8 & 7 & 6 & 5 & 4 & 3 & 2 & 1\end{array}$

In keeping with a commitment to support environmentally responsible and sustainable printing practices, UC Press has printed this book on Natures Natural, a fiber that contains 30\% post-consumer waste and meets the minimum requirements of ANSI/NISO Z39.48-1992 (R 1997) (Permanence of Paper). 
In memory of Jeanette Holt 1964-2014 
This page intentionally left blank 